\title{
REVITALIZATION OF CULTURAL HERITAGE AREA WITH SUSTAINABLE TOURISM APPROACH CASE STUDY: TINDOI FORT, KABUPATEN WAKATOBI
}

Jauhar*, Purwanita Setijanti**, Arina Hayati***

*) Master Student, Department of Architecture, Institute of Technology Sepuluh Nopember, Indonesia

**) Department of Architecture, Institute of Technology Sepuluh Nopember, Indonesia

***) Department of Architecture, Institute of Technology Sepuluh Nopember, Indonesia e-mail: jauhar.blue12@gmail.com

\begin{abstract}
Tindoi Fort continues to be threatened because of not yet getting the community's full support to preserve it. Tindoi Fort should be a valuable asset for the government if it is managed seriously. This study aims to revitalize cultural heritage sites by providing new vitality through a sustainable tourism approach. The study uses a combination of historical interpretative strategies to find out the original form of the Fort through observation and in-depth interviews. Then a qualitative method with a descriptive approach is then used to determine the social character and local community culture to support tourism activities. The results of this study are the formulation of the criteria and concept of revitalization, including the physical restoration of the Fort, the arrangement of tourism based on environmental conservation, the structure of the creative economy centre, the collection of socio-cultural activity areas that support local wisdom attractions.
\end{abstract}

Keywords: revitalization; fort-Tindoi; tourism; sustainable

\section{INTRODUCTION}

As a historical heritage building, the existence of the Tindoi Fort heritage site is expected to reflect a chronological story of a society in the past. Building history can become a tourist attraction and create a distinctive city identity and be a projection of life in the past (Budihardjo and Sidharta, 1989). Site presence Tindoi Fort has received attention from the government. Even Dinas Tourism and Creative Economy, Wakatobi Regency, including the Tindoi Fort area as one of the must-visit tourism objects on the island of Wangi-Wangi (Department of Tourism and Creative Economy, Wakatobi Regency, 2016). However, until now, there has been no serious and consistent handling carried out by the government. This condition results in a 
decrease in physical aspects that can be seen in the state of the layout or layout that has been difficult to identify, the shape and mass of the building, which has mostly collapsed, as well as the circulation network, which is primarily overgrown by trees and shrubs. Meanwhile, if you look at the non-physical aspect, a decrease in vitality may occur in character, which is related to strengthening local characteristics.

Tindoi Fort is one of 5 forts on the island of Wangi-Wangi and 21 forts in Wakatobi Regency (Mansyur et al., 2021). This Fort is thought to be the oldest Fort built on the island of Wangi-Wangi before the entry of Islam into the Wakatobi islands. This can be seen from the absence of Islamic worship buildings (mosques) in Liya Fort in the South Wangi-Wangi District. In addition, inside the Fort, there is the tomb of La Samburaka, who is also suspected of being one of the first people to inhabit the Wangi-Wangi Island.

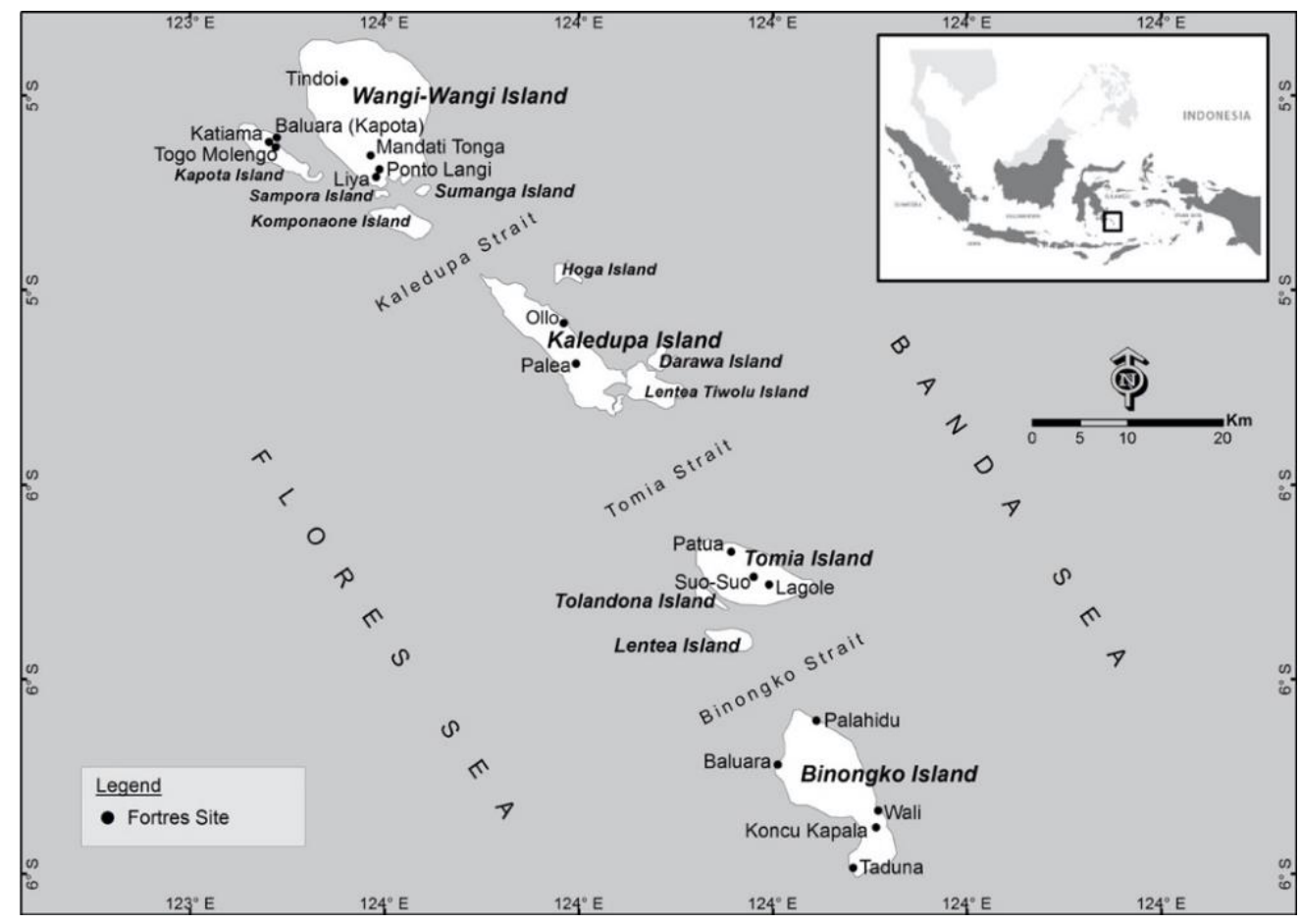

Figure 1. Distribution of Sites on Wakatobi Islands

Source: Regional Agency for Archeological Research in South Sulawesi Province, 2019 in Mansyur et al., 2021

Tindoi Fort is administratively located in Tindoi Timur Village, Kec. Fragrant with an area of $14.53 \mathrm{~km}$ or $6 \%$ of the total area of Wangi-Wangi District. Forest areas and community plantations surround Tindoi Fort. To the north of the Fort are the villages of Seruu and Kampoo Wo'ou, to the east of the fort area, are the towns of Po'okambua, to the south of the fort area, are the villages of Tindoi Fort, Tai' bete, Wuta Mohute, and Sandaha villages, while to the west of the Fort are the villages of Waginopo, Wakokosa, and Re'a. Besides being surrounded by local community villages, Tindoi Fort is adjacent to several leading tourist areas in Wangi-Wangi 
District. Among these tourist areas is the Hanging Park Puncak Toliamba tourist area located in the west; the Darakunti Po'okambua tourist area, which is located in the east; and the historical tourist attraction fort Maleko which is located in the south.

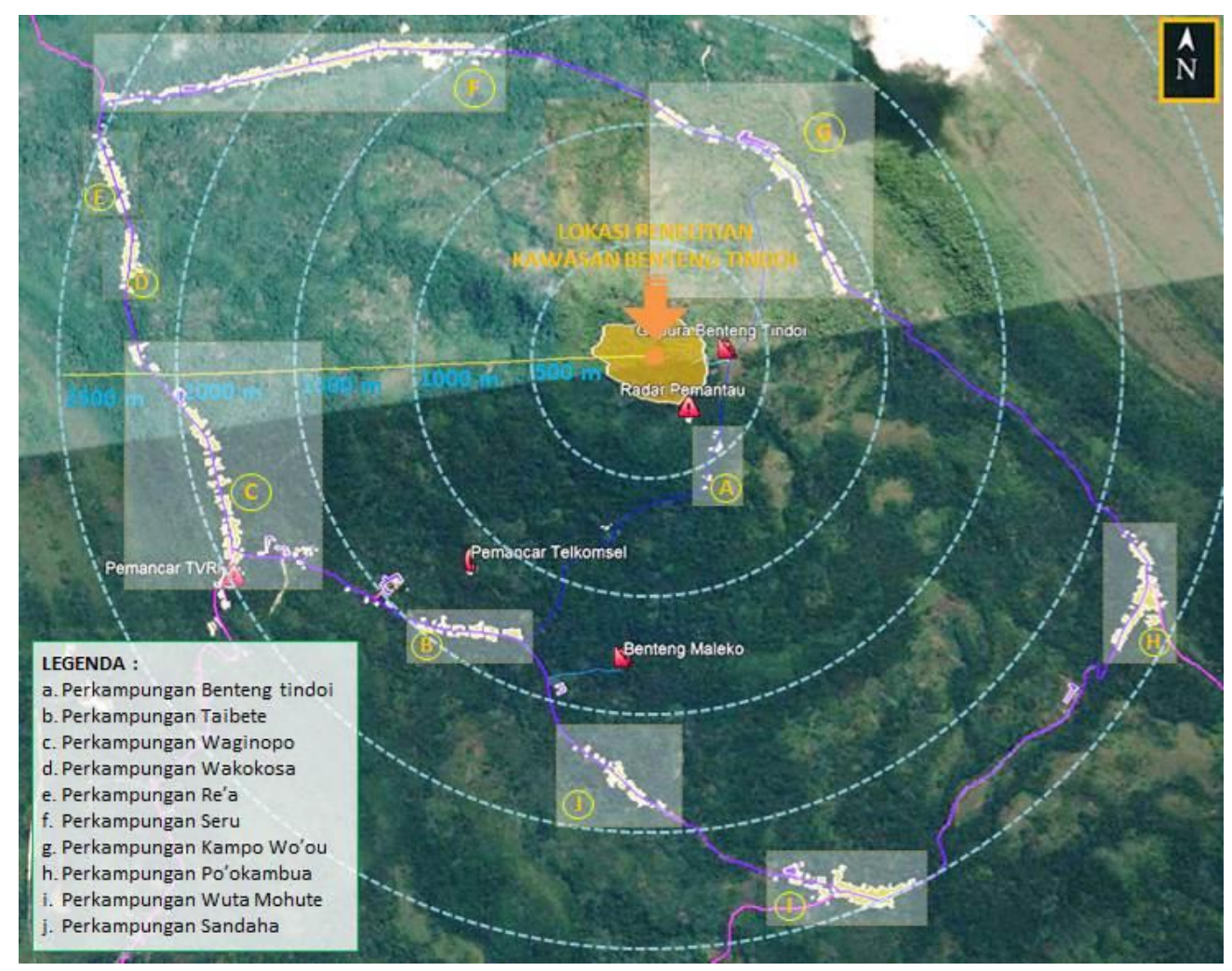

Figure 2. Sketch and Illustration of Research Location Position Source: Google Earth and Author Sketch 2020

The existence of Fort Tindoi can undoubtedly be suspected of having strong emotional ties with the local community, so that historical information on the formation of the fort, social and cultural activities of the community in the early days of the establishment of the Fort is essential knowledge that should be learned material from generation to generation in a sustainable manner. The destruction of historical areas can be caused due to the development and development of sites that are not well done (Danisworo, 2000). Functional, visual, and environmental quality historical look caused by poor regional arrangement itself (Handoko, 2000). When viewed from the side of potential, Tindoi Fort is at the peak of the highest altitude on the island of Wangi-Wang, between 700-800 ft above sea level, so it has an extensive view coverage with beautiful panoramas, besides the existence of a cemetery, ruins of the Fort and the remains of community settlements in the past have its charm, especially historical tourism. In other words, revitalization is carried out in addition to saving historical sites while ensuring its sustainability in the future front by utilizing all the potential tour that belongs. 


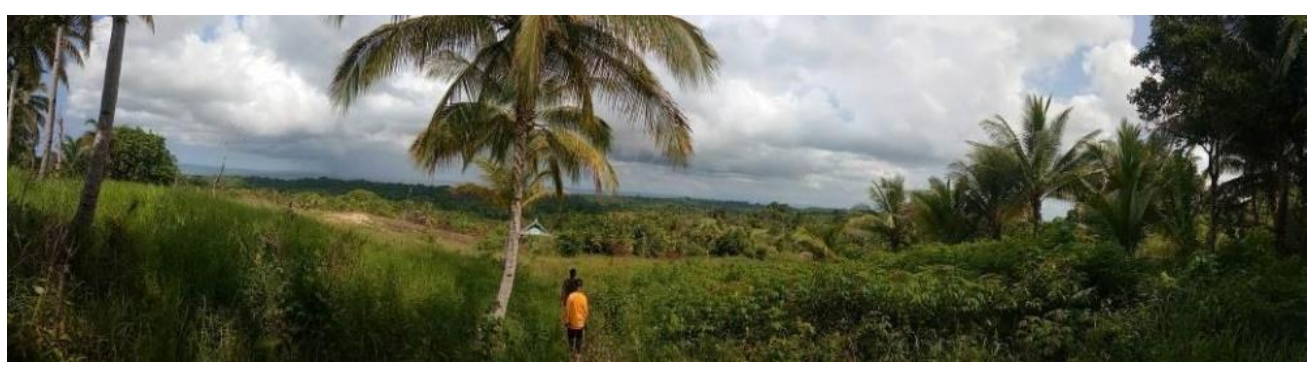

Figure 3. View of the Fort Entrance Area Source: Survey Documentation 2020

Revitalization can be done through three stages, includes physical regeneration, economic renewal, and social rebirth (Danisworo, 1996):

(a) physical revitalization focuses on improving physical aspects, including repair and improvement of conditions building physical, network circulation, and the arrangement of open space. Regarding this statement, urban design elements related to physical features in the form of land use (land use), shape and mass of the building (building form and group), circulation (circulation) and Parking (Parking), outdoor (open space), pedestrians (pedestrian ways), marker (signage), activity supporter (activity support) and conservation (Shirvani, 1985).

(b) economic revitalization, intended to support the physical improvement of the historic area and improve the local economy. Conservation efforts should also be able to provide ways on how to bring benefits economically.

(c) social revitalization. It was done to create an attractive social environment and enhance the dynamics of life and social community.

Sustainable development is significant to designing tourism. With this concept, an area will maintain its existence from time to time and preserve the environment, culture, and local wisdom, and even provide economic stability for the community. (World Tourism Organization (WTO), 2004). sustainable tourism development aims to prioritize utilizing tourism assets for the long term (Butler, 1999). Sustainable tourism development should also consider aspects of the local community (Wall, 1997). There are at least four ways to interpret tourism in the context of sustainable development (Coccossis, 1996): (a) sectoral point of view such as tourism economic sustainability; (b) an ecological point of view that emphasizes the need for ecologically sustainable tourism; (c) the point of view of the long-term viability of tourism, recognizing the competitiveness of the destination; and (d) the viewpoint of accepting tourism as part of a strategy for sustainable development across the physical and human environment. Tourism destination development sustainability should get support from ecological sustainability, be accepted in the socio-cultural life of the community, and provide economic benefits (Suwena and Widyatmaja, 2010). In other words, revitalization efforts on research objects are interrelated and support sustainable tourism development. Revitalization has unidirectional development goals with sustainable development. Regeneration plays a role in realigning urban assets to give new vitality or even revive energy that has begun to be forgotten (Martokusumo, 2008). 
Various sources of theory revitalization and mutually sustainable tourism support each other. The revitalization includes improving physical value, increasing economic value, and community social activities. Meanwhile, sustainable tourism development must consist of ecological sustainability, financial sustainability, social and culture so that tourism objects can survive and are feasible for an indefinite period. Thus, sustainable tourism-based revitalization is an effort to develop historical heritage objects into a tourism destination by utilizing local communities' environmental, economic, social, and cultural potential so that the vitality value of historical heritage objects can be returned and remain viable in an indefinite period.

Given the importance of the Tindoi Fort cultural heritage and its potential for tourism development, it is essential to carry out this revitalization effort. Aside from preserving historical heritage sites, the revitalization of Tindoi Fort aims to provide opportunities for the community to develop their environmental potential and local wisdom. To improve economic life sustainably in the future. The importance of historical heritage can continue to be enhanced, which in the end The public can know that the development of tourist objects is not just bringing tourists to places where they are a historical relic and watch it, but also how to introduce historical heritage assets so that they are better known by the public (Sarfiah, 1993).

\section{RESEARCH METHODS}

The research was conducted with a combination of historical interpretative strategies to find out the original form of the Fort through in-depth observations and interviews on critical sources (guardians of the fort and local historians), then a qualitative strategy with a descriptive approach. To dig deeper into local community character to support sustainable tourism activities that are applied to the research location through observation and interviews.

To carry out physical revitalization, as a first step, the research focused on identifying the original form of the Tindoi fort in terms of the layout of the Fort, the shape and mass of the building, and its circulation network orientation in the past. This is useful for determining the restoration of the physical area of the Fort. Next, identify economic, social, and cultural sustainability aspects to develop design criteria and appropriate design concepts to be set at the research site.

Research with interpretative historical strategies is carried out through three stages, namely identification (in-depth interviews, surveys, and observations), organization, and evaluation. While the qualitative strategy is carried out with the stages of data collection (interviews, surveys, and observations), data reduction, data presentation, and concluding. The resource persons in the study were selected based on the representative method by selecting key informants from cultural circles/local historians and caretakers of the fort, then selecting supporting/comparative sources from the local government and stakeholders such as village officials, related communities, residents, and tourists (local and foreign).

\section{RESULT AND DISCUSSION}




\section{Theoretical Discussion}

Revitalization is carried out in the research area by utilizing the potential, and local wisdom possessed. Various potential advantages of land and the value of rich local understanding synergize to form a sustainable tourism destination. If you look at the current condition of the Fort, of course, it is far from sustainable. For this reason, revitalization efforts with a sustainable tourism approach are carried out. In Martokusumo (2008) theory, it is said that revitalization is not only done to increase or revive existing vitality but can also be done by providing new vitality. In the context of research, it is no longer possible to revive existing or even existing energy. In this case, the social life of the people in the Fort. This is because the fort area is not currently a Tindoi protected forest conservation area and is contrary to the local government's tourism development policy (RIPPARDA Wakatobi, 2016). Revitalization efforts are carried out by providing new vitality in the form of developing sustainable tourism destinations. By utilizing Tindoi Fort as a tourist attraction, the value of local wisdom of the community, both socio-cultural, can simultaneously support Tindoi Fort tourism and at the same time improve the economy of the local community.

Knowing the original form of the Fort using urban design elements as the first step in the physical revitalization efforts carried out is related to the research of Handoko (2011) related to the reconstruction of the physical elements of the Fort. This shows the importance of reconstructing cultural heritage assets that have been damaged to be returned to their original form. The revitalization of the physical elements of the Fort must be a significant concern and is the first step in revitalization efforts. Danisworo (2002) supports this statement, which places physical revitalization in the first stage before revitalizing the social economy.

Sustainable tourism development is essential to do in the current management of tourism destinations. Wall (1996) emphasizes meeting current needs while protecting opportunities for the sustainability of tourism assets. In other words, the current priority scale and the development and management of tourism asset management. In the context of research, the preservation of the Tindoi Fort cultural heritage site is currently a priority because it continues to experience self-destruction from time to time. This condition is feared to be more severe if not treated seriously. Meanwhile, Coccossis (1996) and Butler (1999) emphasize long-term sustainability indefinitely and sustainable development strategies. In other words, it refers to tourism management and development strategies. This means that the management and development of tourism also require support from various elements of society, government, and related stakeholders. In this way, sustainable tourism development can be realized. 

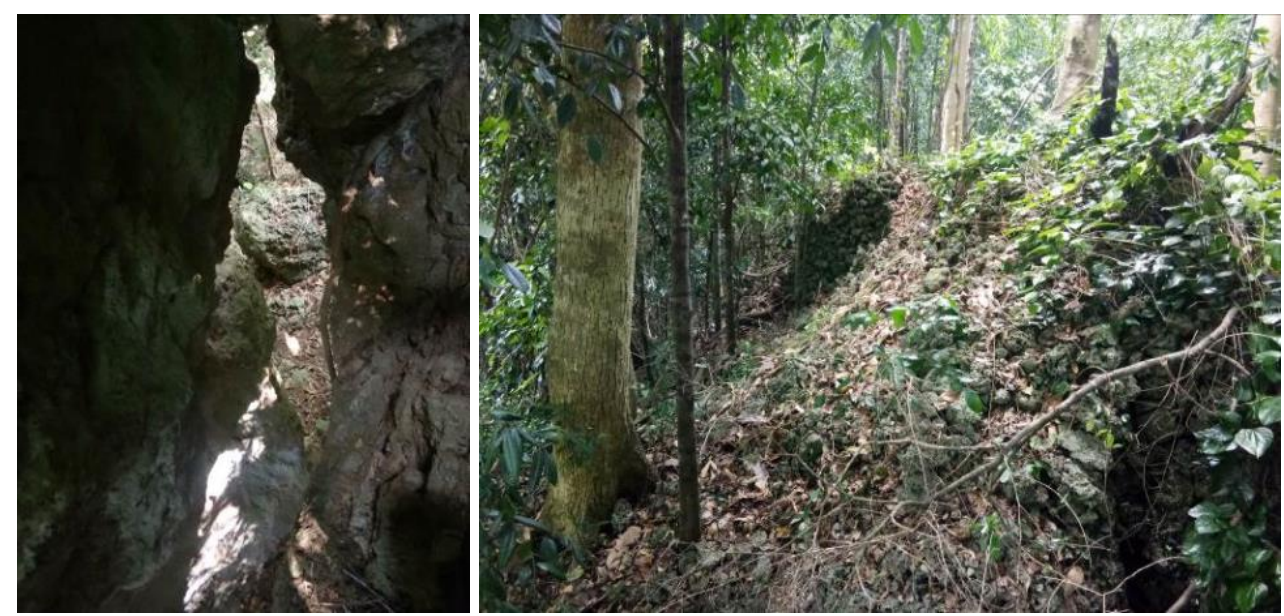

Figure 4. (Left) Cave in The Fort, (Right) Castle Ruins Source: Survey Documentation 2020

The development of sustainable tourism destinations certainly cannot apply all aspects of tourism sustainability to various tourism assets, requiring adjustments to the object to be studied. In the context of the research area, the location of Tindoi Fort is an inland area that has not been well supported by city infrastructure and tourism needs, so identification and analysis of urban design elements need to be done to complement the availability of supporting infrastructure and support sustainable tourism development. If examined more deeply, the eight elements of urban design proposed by Shirvani (1985) are indirectly related to tourism development. To ensure the sustainability of tourism, various supporting activities are needed to be realized into the utilization of the potential (environmental, economic, social, cultural) at the Tindoi fort. Meanwhile, other urban design elements in the form of circulation and parking, pedestrian areas, signage are elements of tourism infrastructure and are complementary, while elements of land use, shape, and mass of buildings are used as the basis for structuring tourism destinations.

\section{Physical Aspect}

In the perspective of urban design, the physical elements are related to the main features forming the city, such as individual and mass buildings and supporting physical aspects such as road networks, plazas, parking areas, and other physical elements of the town. Urban design elements are related to the city's physical characteristics, namely: land management, building mass formation, circulation network, open space arrangement, walking paths, area markers, supporting activities, and conservation areas (Shirvani, 1985). The purpose of this physical revitalization is to restore its physical form as before and achieve a better visual appearance. Meanwhile, element area graphics related to physical elements, including buildings (buildings), landscaping (landscaping), Parking (parking), and the arrangement of signs or markers (Berry, 1980). 
Physical elements have a broad meaning. For this reason, in the context of this research, it will be more focused on the urgent priority scale for revitalization. The focus of physical elements in the study relates to the land arrangement, the formation of the building period, circulation network, and its orientation.

Table 1. Physical Aspect Analysis

\begin{tabular}{|c|c|c|c|}
\hline No & Sub Aspect & Analysis result (the past) & $\begin{array}{c}\text { Identification result (present } \\
\text { time) }\end{array}$ \\
\hline 1 & $\begin{array}{l}\text { Land Use } \\
\text { Shape and } \\
\text { mass }\end{array}$ & $\begin{array}{l}\text { Tindoi Fort consists of } 3 \\
\text { layers: } \\
\text { - Layer } 1(\text { bottom })= \pm 3.8 \text { ha } \\
\text { - Layer } 2(\text { Middle })= \pm 1.5 \mathrm{ha} \\
\text { - Layer } 3(\text { Top })= \pm 0.4 \mathrm{ha} \\
\end{array}$ & $\begin{array}{l}\text { Leaving } 2 \text { Layers: } \\
\text { - Layer } 2 \text { (Middle })= \pm 1.5 \text { ha } \\
\text { - Layer } 3(\text { Top })= \pm 0.4 \text { ha } 5 \mathrm{~m}\end{array}$ \\
\hline 2 & $\begin{array}{l}\text { Shape and } \\
\text { mass }\end{array}$ & $\begin{array}{l}\text { Building Height: } \\
\text { The fort is arranged following } \\
\text { the contours of the land with } \\
\text { an average height of } 80-100 \\
\mathrm{~cm} \\
\text { Style and Material: } \\
\text { The characteristic of the } \\
\text { ancient fort architecture of } \\
\text { Wakatobi is the arrangement } \\
\text { of stones without ornaments } \\
\text { and adhesives. } \\
\text { Texture and color: } \\
\text { The stone texture is rough and } \\
\text { hollow with the original color } \\
\text { of the rocks. } \\
\text { Building mass: } \\
\text { Two types of building masses, } \\
\text { namely residential } \\
\text { buildings/residential buildings, } \\
\text { and one public area, namely } \\
\text { places of worship. }\end{array}$ & $\begin{array}{l}\text { Building Height: } \\
\text { Most of the forts have collapsed } \\
\text { with varying heights between } 30 \\
\mathrm{~cm} \text { and } 60 \mathrm{~cm} \text { on the ruins while } \\
80 \mathrm{~cm} \text { on the fields that are still } \\
\text { intact. } \\
\text { Style and Material: } \\
\text { There are two types of fort styles } \\
\text { with different shapes and } \\
\text { materials. Style } 1 \text { (arranged with } \\
\text { parallel surfaces without using } \\
\text { cement as adhesive). Style } 2 \\
\text { (composed with game ornaments } \\
\text { on the top and using cement as } \\
\text { adhesive) } \\
\text { Building mass: } \\
\text { There are no building masses } \\
\text { within the fort. Residents' } \\
\text { settlements are in front of the fort } \\
\text { area }\end{array}$ \\
\hline 3 & $\begin{array}{l}\text { Circulation } \\
\text { and parking }\end{array}$ & $\begin{array}{l}\text { The circulation pattern is only } \\
\text { formed in the village area and } \\
\text { the road network to the } \\
\text { plantations } \\
\text { There are four entrances to the } \\
\text { fort area following the cardinal } \\
\text { directions. }\end{array}$ & $\begin{array}{l}\text { Circulation is not well connected. } \\
\text { There is no access path to explore } \\
\text { the fort (only in the area within } \\
\text { the fort) } \\
\text { Parking area not yet available }\end{array}$ \\
\hline 4 & Orientation & $\begin{array}{l}\text { The beginning of the main } \\
\text { entrance was in the west }\end{array}$ & $\begin{array}{l}\text { Main entrance moves to the east } \\
\text { of the fort area (orientation has } \\
\text { changed) }\end{array}$ \\
\hline
\end{tabular}

Source: Observation, 2020

From the analysis of the physical aspects, it was found that the original shape of the Fort today has changed a lot. The most notable changes could be seen in the 
area of the Fort, which has been drastically reduced. Leaves two layers or regions. Most of the Fort has fallen, leaving in some areas. This condition is because you are under the state of the Fort that continues to be neglected. The following is an illustration of the need of the Fort in the past and the results of observations of the Fort in the present:

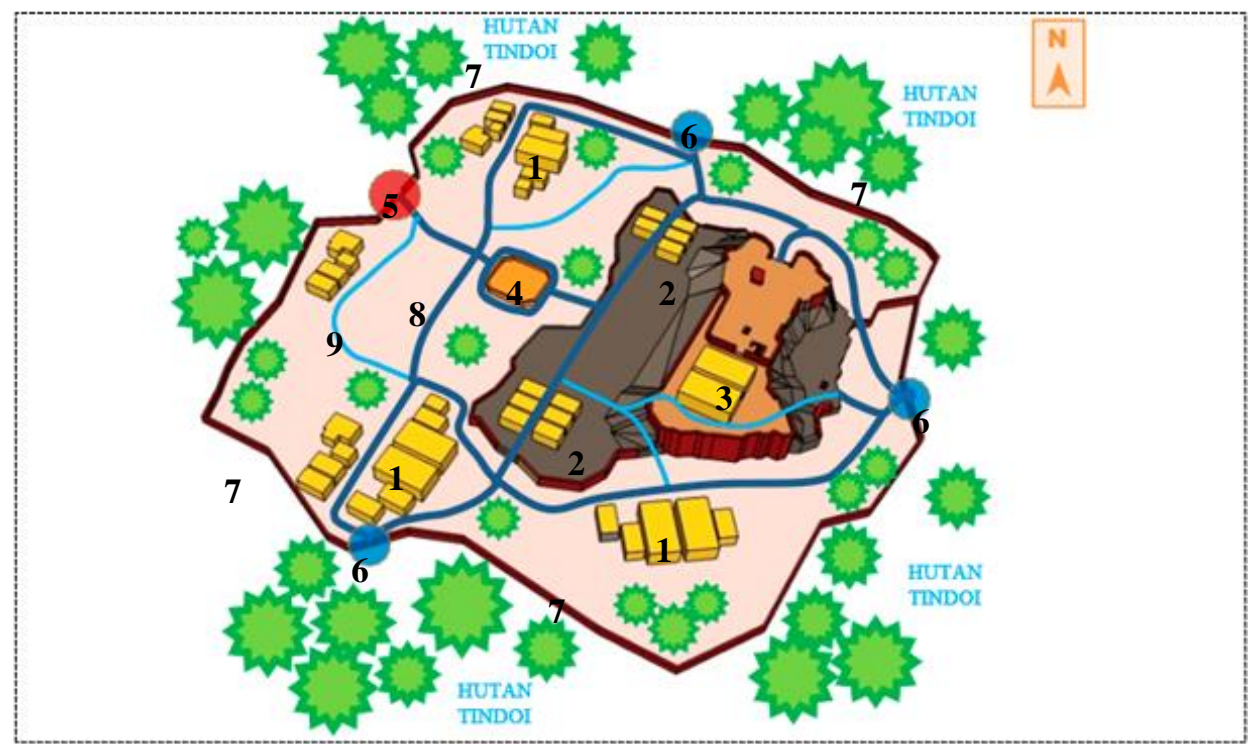

Figure 5. Illustration of the Form of the Fort in the Past Source: field survey, 2020

Notes of Figure 5:

1.Layer $1 \pm 3.8$ ha (Settlement general public)

2.Layer $2 \pm 1.5$ ha (Soldier/Guard Settlement)

3. Layer $3 \pm 0.4$ ha (La Samburaka Special Residence)

4. Worship Area

5.Main Entertainment

6. Side Entrance

7. Castle Fence

8. Main road

9. Secondary Road (Connector)

Characteristics of the Castle in the past (Figure 5):

1.The fort is arranged with an average height of $80-100 \mathrm{~cm}$ following the contours of the land

2. Consists of two mass buildings (residential buildings and places of worship)

3. There are four entrances following the direction of the eye wind and formed in residential areas towards plantations

4. Orientation and main entrance area on the west side 


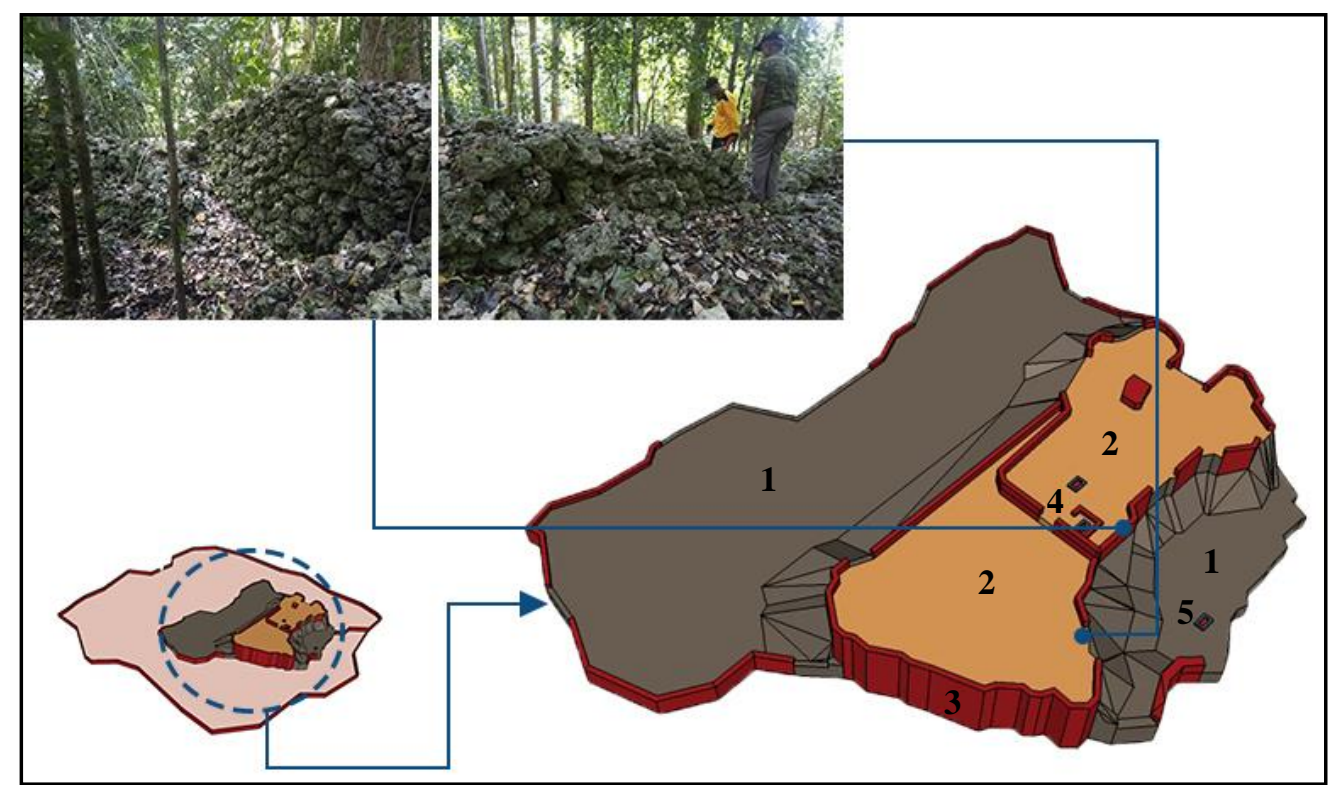

Figure 6. The Current Condition of The Fort Source: field survey, 2020

Notes of Figure 6:

1.Layer 2

2.Layer 3

3. Fort Wall

4. Tomb of La Samburaka and Waode Orio

5. Grave Bontu

Current Fortress Characteristics (Figure 6):

1.Leaving 2 layers (layer middle an area of \pm 1.5 ha and a layer of on \pm 0.4 ha

2. Most of the fort has fallen (fallen part 30-60 cm and whole parts $80-100 \mathrm{~cm}$ )

3.There are no building masses anymore in the fort, leaving only the fort fence

4. The fort fence is made of stone that is dundun without any adhesive.

5. Circulation and Parking are not well available

6. The orientation of the building has changed from the main entrance to the west, now to the east

By referring to the condition of the fort in the past, the fort currently requires physical revitalization efforts in the form of restoring the fort area by reconstructing the ruin area following its original form. Physical revitalization carried out is limited to development including:

1. Reconstruct the remaining fort ruins area (in layer 2 and 3 areas)

2. Reorganizing the circulation network that facilitates fort exploration

3. The current orientation of the fort will be maintained with consideration of ease of accessibility

4. Restoring the location of the fort so that it can support tourism later 

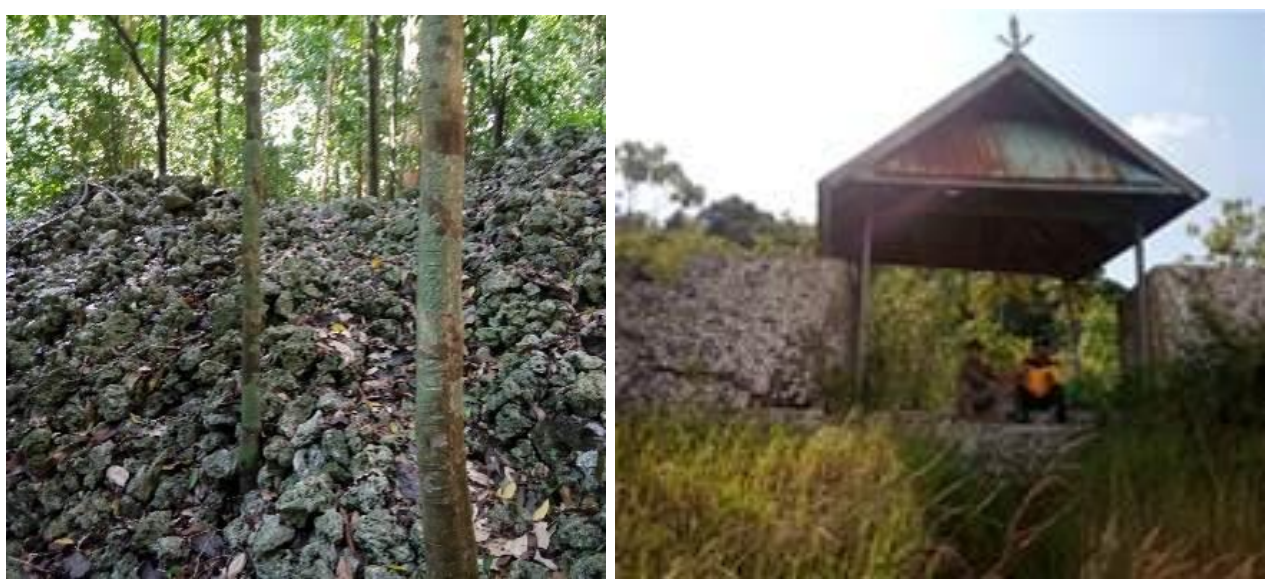

Figure 7. (Left) Castle Ruins (Right) Entrance Gate

Source: field survey, 2020

\section{Economic Aspect}

The income of the Tindoi community's economic sector is dominated by the work of dryland farmers. Based on a review of the research location and the results of interviews with the surrounding community, there are various kinds of plantations owned by residents, including coconut plantations, coffee plantations, cashew plantations, palm plantations, plantations of daily necessities such as vegetables, fruits, and tubers. The economic condition of the Tindoi community is quite difficult. This is contrary to its natural potential. On the other side, sustainable tourism development's goal is to provide welfare to the local community, especially where the destination is located. (Butler, 1999). In other words, the economic welfare of the community must shouldn't be ignored.

Table 2. Economic Aspect Analysis

\begin{tabular}{lll}
\hline No & $\begin{array}{l}\text { Economic } \\
\text { potential }\end{array}$ & \multicolumn{1}{c}{ Development Potential Analysis } \\
\hline 1 & $\begin{array}{l}\text { Local } \\
\text { specialties }\end{array}$ & $\begin{array}{l}\text { Wakatobi's various culinary delights have a distinctive and unique } \\
\text { taste. } \\
\text { Can be used to support research sites by developing local culinary } \\
\text { tourism. }\end{array}$ \\
\hline 2 & $\begin{array}{l}\text { Local } \\
\text { specialty }\end{array}$ & $\begin{array}{l}\text { The existence of various local handicrafts has its charm. } \\
\text { These various kinds of special crafts can be used as a source of } \\
\text { community income as well as support creative economic } \\
\text { empowerment at the research location. }\end{array}$ \\
\hline 3 & $\begin{array}{l}\text { Tourism } \\
\text { Management }\end{array}$ & $\begin{array}{l}\text { The surrounding community can be involved in tourism } \\
\text { management, as well as improving the community's economy. }\end{array}$ \\
\hline & &
\end{tabular}




\begin{tabular}{cll}
\hline No & $\begin{array}{l}\text { Economic } \\
\text { potential }\end{array}$ & \multicolumn{1}{c}{ Development Potential Analysis } \\
\hline 4 & $\begin{array}{l}\text { Plantation } \\
\text { Potential }\end{array}$ & $\begin{array}{l}\text { Various kinds of plantations in the surrounding community include } \\
\text { coconut plantations, coffee, cashew, palm sugar, vegetables, fruits, } \\
\text { and tubers. } \\
\text { Various plantation products are usually sold to traditional markets } \\
\text { and privately consumed. } \\
\text { The existence of plantations around the research location can be } \\
\text { used as potential to support tourism needs. }\end{array}$ \\
\hline & $\quad$ Source: Observation, 2020
\end{tabular}

\section{Social Aspect}

Since ancient times the people of Wakatobi have been accustomed to living together. This habit is reflected in their daily life, and cultural traditions and the way found several public areas that the surrounding community calls "gode-gode" (guardhouse). "Gode-gode" is usually used by people to socialize and spend time together to talk about various things.

The community's social life with the culture of "gotong-royong" as a cultural heritage of the past can sometimes still be found in house building events that work for hand in hand to help, especially in installing the roof frame house. This community habit has an efficient value, especially in maintaining harmonious social relations; it will be unfortunate if this positive culture is abandoned and cannot be enjoyed by the next generation. In response to this, the development of tourism destinations must also be one of the solutions to revive the social values of the society that have begun to be abandoned. Providing public spaces as a forum for local community socialization will significantly help restore, strengthen, and maintain the community's social life that has been passed down from generation to generation.

Table 3. Social Aspect Analysis

\begin{tabular}{cll}
\hline No & $\begin{array}{l}\text { Social Activities } \\
\text { (Habits) }\end{array}$ & \multicolumn{1}{c}{ Development Potential Analysis } \\
\hline 1 & $\begin{array}{l}\text { Mutual } \\
\text { Cooperation } \\
\text { Culture }\end{array}$ & $\begin{array}{l}\text { The community has a culture of cooperation that helps each } \\
\text { other, especially in traditional events, weddings, and house } \\
\text { construction (installation of roof trusses). } \\
\text { This habit must be preserved to maintain community social } \\
\text { relations by giving responsibility for managing tourism, as } \\
\text { well as maintaining the culture of cooperation and improving } \\
\text { the economy of the local community. }\end{array}$ \\
& $\begin{array}{l}\text { The habit of people who often gather is teased (public space) } \\
\text { to just tell stories, spend time together while protecting the } \\
\text { environment. } \\
\text { This habit must be preserved to maintain community social } \\
\text { relations by providing public space for the community at the } \\
\text { socialization }\end{array}$ \\
& &
\end{tabular}




\begin{tabular}{clc}
\hline No & $\begin{array}{l}\text { Social Activities } \\
\text { (Habits) }\end{array}$ & Development Potential Analysis \\
\hline 3 & $\begin{array}{l}\text { Local special } \\
\text { games }\end{array}$ & It is a regional game and supports attractive tourism \\
\hline & & Source: Observation, 2020
\end{tabular}

Source: Observation, 2020

\section{Cultural Aspect}

In general, Wakatobi has a variety of cultural customs that have been passed down from generation to generation. From a variety of attractive cultures, community cultural customs related to arts and crafts, traditional ceremonies, cultural celebrations in social life, even traditional games from the region also contribute to the diversity and richness of the culture they have. Sources from cultural observers said that there are so many Wakatobi customs and culture, especially the Tindoi community and most of them have not been widely exposed among the general public. There are many types of attractive culture and traditional games that even the current generation doesn't know about.

The wealth of cultural customs that is owned is a potential that will be used to support tourism development in the object of research for Tindoi Fort. Providing infrastructure and all its facilities will be done to attract tourists and the surrounding community so that all these cultural customs can be preserved and maintained from time to time.

Table 4. Cultural Aspect Analysis

\begin{tabular}{|c|c|c|c|}
\hline No & Culture/Art & $\begin{array}{l}\text { Social Activities } \\
\text { (Habits) }\end{array}$ & Development Potential Analysis \\
\hline 1 & Dance & $\begin{array}{ll}\text { a. Lariangi dance } \\
\text { b. Hebalia dance } \\
\text { c. Bungkele Sombo } \\
\text { Dance } \\
\text { d. Honari dance } \\
\text { e. Borira dance } \\
\text { f. Wowine dance } \\
\text { g. moane dance } \\
\text { h. Saride dance } \\
\text { i. Balumpa dance } \\
\text { j. Pakenta-kenta dance } \\
\text { k. }\end{array}$ & $\begin{array}{l}\text { 1.Can be developed into an attractive } \\
\text { cultural performance periodically at the } \\
\text { research location } \\
\text { 2. Adding tourist attraction } \\
\text { 3. Has a cultural tourism attraction }\end{array}$ \\
\hline 2 & $\begin{array}{l}\text { Attractive } \\
\text { Traditional } \\
\text { Art }\end{array}$ & $\begin{array}{l}\text { a. Karia'a traditional } \\
\text { party } \\
\text { b. Martial arts tradition } \\
\text { c. Safari traditional } \\
\text { party } \\
\text { d. Kabuenga traditional } \\
\text { ceremony }\end{array}$ & $\begin{array}{l}\text { 1. Can be developed into an attractive } \\
\text { cultural performance periodically at the } \\
\text { research location } \\
\text { 2. Has a cultural tourism attraction } \\
\text { (attractive traditional art) } \\
\text { 3. Adding tourist attraction }\end{array}$ \\
\hline
\end{tabular}




\begin{tabular}{|c|c|c|c|}
\hline No & Culture/Art & $\begin{array}{c}\text { Social Activities } \\
\text { (Habits) }\end{array}$ & Development Potential Analysis \\
\hline & & $\begin{array}{l}\text { e. Karia'a traditional } \\
\text { ceremony } \\
\text { f. Mbule-mbule } \\
\text { traditional ceremony }\end{array}$ & \\
\hline 3 & Local Crafts & $\begin{array}{l}\text { a. Homoru } \\
\text { b. Webbing } \\
\text { c. Coconut shell crafts } \\
\text { d. Blacksmith's Craft }\end{array}$ & $\begin{array}{l}\text { 1. Can be developed into souvenirs } \\
\text { typical of the area at the research } \\
\text { location. } \\
\text { 2. Supporting creative economic } \\
\text { activities } \\
\text { 3. Adding tourist attraction }\end{array}$ \\
\hline
\end{tabular}

Source: Observation, 2020

Based on the results of the research conducted, the revitalization design with a sustainable tourism approach that is applied to the Tindoi Fort research location must balance in a balanced way the various environmental, economic, social, and cultural potentials possessed to form a tourism destination based on the preservation of cultural heritage with attractiveness and local wisdom of the community.

\section{Design Criteria and Concepts}

Table 5. Design Criteria and Concepts

\begin{tabular}{|c|c|c|c|c|}
\hline No & Aspect & Synthesis & Design Criteria & Design Concept \\
\hline 1 & $\begin{array}{l}\text { Physical } \\
\text { Aspect: }\end{array}$ & $\begin{array}{l}\text { With the current } \\
\text { condition of the fort, } \\
\text { the fort must be } \\
\text { restored following } \\
\text { the original } \\
\text { condition of the fort } \\
\text { in the past, with the } \\
\text { following } \\
\text { limitations: } \\
\text { 1. the castle layout } \\
\text { will not be restored } \\
\text { in its entirety, retain } \\
\text { the current layout } \\
\text { (consisting of two } \\
\text { layers) } \\
2 . \text { The remaining } \\
\text { ruins will be } \\
\text { reconstructed back }\end{array}$ & $\begin{array}{l}\text { The design pays } \\
\text { attention to the } \\
\text { sustainability of the } \\
\text { physical } \\
\text { environment. } \\
\text { The design of the } \\
\text { physical } \\
\text { revitalization of the } \\
\text { fort continues to pay } \\
\text { attention to local } \\
\text { customary rules and } \\
\text { regulations } \\
\text { Land use: } \\
\text { Grouping various } \\
\text { types of supporting } \\
\text { activities and } \\
\text { integrating them into } \\
\text { land-use zoning }\end{array}$ & $\begin{array}{l}\text { 1. Divide the land into } \\
\text { three main parts, } \\
\text { namely, a tourism area } \\
\text { based on environmental } \\
\text { conservation, a socio- } \\
\text { cultural-based tourism } \\
\text { area, and an area for } \\
\text { creative economic } \\
\text { development. } \\
\text { 2. Integrating forms of } \\
\text { local wisdom in land } \\
\text { management and } \\
\text { various physical forms } \\
\text { of tourism supporting } \\
\text { buildings } \\
\text { 3. Provide and organize } \\
\text { infrastructure }\end{array}$ \\
\hline
\end{tabular}




\begin{tabular}{|c|c|c|c|c|}
\hline No & Aspect & Synthesis & Design Criteria & Design Concept \\
\hline & & $\begin{array}{l}\text { to their original } \\
\text { form } \\
\text { 3. Reorganizing } \\
\text { circulation that } \\
\text { supports fort } \\
\text { tourism activities } \\
\text { Land use: } \\
\text { The potential of the } \\
\text { land has not been } \\
\text { fully utilized. The } \\
\text { land-use planning of } \\
\text { the research area } \\
\text { will be more } \\
\text { emphasized on the } \\
\text { use of a mixed land } \\
\text { use plan, by } \\
\text { developing various } \\
\text { supporting activities } \\
\text { within the area such } \\
\text { as tourism } \\
\text { development, } \\
\text { creative economic } \\
\text { zones, social and } \\
\text { cultural activities. } \\
\text { Building form and } \\
\text { mass: } \\
\text { The architectural } \\
\text { appearance of } \\
\text { Tindoi Fort is still } \\
\text { preserved. The } \\
\text { impression } \\
\text { generated from the } \\
\text { appearance of this } \\
\text { fort is very natural } \\
\text { and blends with the } \\
\text { environment. } \\
\text { design. } \\
\text { Circulation and } \\
\text { Parking: } \\
\text { Circulation is not } \\
\text { well connected. } \\
\text { Requires } \\
\text { realignment to all } \\
\text { aspects of } \\
\text { circulation in the } \\
\text { research location. }\end{array}$ & $\begin{array}{l}\text { Building Shape and } \\
\text { Mass: } \\
\text { 1. As much as } \\
\text { possible integrate } \\
\text { the typical } \\
\text { architectural style of } \\
\text { the fort in the design } \\
\text { 2. Applying } \\
\text { elements of local } \\
\text { wisdom in the form } \\
\text { of regional layouts. } \\
\text { Circulation and } \\
\text { Parking: } \\
\text { 1. As much as } \\
\text { possible integrate } \\
\text { every element of } \\
\text { circulation required } \\
\text { at the research site } \\
\text { 2. Providing parking } \\
\text { space with } \\
\text { consideration in } \\
\text { Shirvani (1985) }\end{array}$ & $\begin{array}{l}\text { supporting the } \\
\text { exploration of } \\
\text { protected forests that } \\
\text { are environmentally } \\
\text { friendly and minimize } \\
\text { damage to the forest } \\
\text { environment and its } \\
\text { ecosystem } \\
\text { 4. Organize the land by } \\
\text { making the Tindoi fort } \\
\text { a focal point. } \\
\text { 5. Organizing the } \\
\text { circulation network to } \\
\text { support exploratory } \\
\text { tourism at the Tindoi } \\
\text { fort } \\
\text { 6. The arrangement of } \\
\text { the building mass is } \\
\text { adjusted to the function } \\
\text { of the land } \\
\text { 7. Arrange parking } \\
\text { areas that are easily } \\
\text { affordable and } \\
\text { adequate and place } \\
\text { public transport } \\
\text { parking lots that have a } \\
\text { large capacity at the } \\
\text { outermost entrance } \\
\text { such as tourist buses } \\
\text { 8. Placing the main } \\
\text { entrance in an area that } \\
\text { is easily accessible and } \\
\text { found and providing } \\
\text { public transportation } \\
\text { facilities in the area of } \\
\text { the main entrance of } \\
\text { the area. }\end{array}$ \\
\hline
\end{tabular}




\begin{tabular}{|c|c|c|c|c|}
\hline No & Aspect & Synthesis & Design Criteria & Design Concept \\
\hline & & $\begin{array}{l}\text { Orientation: } \\
\text { The change in the } \\
\text { orientation of the } \\
\text { fort is currently } \\
\text { following the } \\
\text { development of a } \\
\text { new road network } \\
\text { developed by the } \\
\text { government. }\end{array}$ & & \\
\hline \multirow[t]{4}{*}{2} & Economy & $\begin{array}{l}\text { The local benefits of } \\
\text { the surrounding } \\
\text { community have the } \\
\text { potential to be } \\
\text { utilized to ensure } \\
\text { economic } \\
\text { sustainability in the } \\
\text { future. }\end{array}$ & $\begin{array}{l}\text { 1. Utilizing various } \\
\text { community } \\
\text { economic potentials } \\
\text { such as local } \\
\text { culinary specialties, } \\
\text { handicrafts, and } \\
\text { plantation potential } \\
\text { to support the local } \\
\text { community's } \\
\text { economy. }\end{array}$ & $\begin{array}{l}\text { 1. Providing facilities } \\
\text { to support the } \\
\text { community's economy } \\
\text { such as retail } \\
\text { 2. Providing } \\
\text { infrastructure facilities } \\
\text { for resource processing } \\
\text { and community craft } \\
\text { industry }\end{array}$ \\
\hline & & & $\begin{array}{l}\text { 2. involve the } \\
\text { surrounding } \\
\text { community as a } \\
\text { tourism destination } \\
\text { manager }\end{array}$ & $\begin{array}{l}\text { 3. Provide and organize } \\
\text { local culinary facilities } \\
\text { and infrastructure } \\
\text { which are jointly } \\
\text { managed by the } \\
\text { community and various } \\
\text { related parties to } \\
\text { improve the tourism } \\
\text { economy }\end{array}$ \\
\hline & & & & $\begin{array}{l}\text { 4. Providing building } \\
\text { facilities for the } \\
\text { management and } \\
\text { development of the } \\
\text { tourism economy }\end{array}$ \\
\hline & & & & $\begin{array}{l}\text { 5. Develop a strategic } \\
\text { management and } \\
\text { development plan to } \\
\text { increase tourism } \\
\text { economic income } \\
\text { sustainably. }\end{array}$ \\
\hline 3 & $\begin{array}{l}\text { Social } \\
\text { and } \\
\text { Cultural }\end{array}$ & $\begin{array}{l}\text { 1. The community } \\
\text { has positive habits } \\
\text { that should be } \\
\text { preserved, such as a } \\
\text { culture of }\end{array}$ & $\begin{array}{l}\text { 1. Preserving } \\
\text { positive community } \\
\text { habits such as } \\
\text { cooperation and } \\
\text { socialization so that }\end{array}$ & $\begin{array}{l}\text { 1. Providing } \\
\text { infrastructure to } \\
\text { support community } \\
\text { social activities }\end{array}$ \\
\hline
\end{tabular}




\begin{tabular}{|c|c|c|c|c|}
\hline No & Aspect & Synthesis & Design Criteria & Design Concept \\
\hline & & $\begin{array}{l}\text { cooperation and } \\
\text { socialization. } \\
\text { Meanwhile, social } \\
\text { potential such as } \\
\text { local games can be } \\
\text { used to support } \\
\text { activities in tourism } \\
\text { development. } \\
\text { 2. Wakatobi has } \\
\text { cultural diversity } \\
\text { such as dance, } \\
\text { attractive cultural } \\
\text { arts, and local } \\
\text { handicrafts. This } \\
\text { potential should be } \\
\text { used to increase } \\
\text { tourist attraction at } \\
\text { the research site. }\end{array}$ & $\begin{array}{l}\text { they remain } \\
\text { sustainable } \\
\text { 2. Take advantage of } \\
\text { local special games } \\
\text { to increase tourist } \\
\text { interest } \\
\text { 3. Utilizing various } \\
\text { cultural potentials of } \\
\text { the community such } \\
\text { as dance, attractive } \\
\text { traditional arts, and } \\
\text { local handicrafts to } \\
\text { add to the tourist } \\
\text { attraction. }\end{array}$ & $\begin{array}{l}\text { 2. Arrange the } \\
\text { landscape area to make } \\
\text { it an open area for the } \\
\text { local community } \\
\text { 3. Organize and } \\
\text { provide facilities for } \\
\text { attractions and local } \\
\text { cultural performances } \\
\text { for the community } \\
\text { 4. Provide facilities and } \\
\text { infrastructure that can } \\
\text { support the cultural } \\
\text { values of the } \\
\text { community such as } \\
\text { cultural studios, arts } \\
\text { and crafts studios for } \\
\text { the local community } \\
\text { 5. Provide educational } \\
\text { facilities or forums that } \\
\text { can improve } \\
\text { community human } \\
\text { resources, especially in } \\
\text { the social and cultural } \\
\text { fields }\end{array}$ \\
\hline
\end{tabular}

Source: Observation, 2020

\section{CONCLUSION}

1. From the research conducted, it is known that there is a significant difference between the shape of the fort in the present and the original form of the fort in the past. Most of the physical damage to the fort is caused because it has been neglected for a long time so that it experiences (self-destruction). Required restoration and reconstruction of the physical elements of the fort in the form of:

- Restoration and reconstruction of the remaining ruins of the current fort to return to its original form.

- Rearrange the circulation network that connects all areas within the fort to support the exploration of the fort as a whole.

- Adjusted the orientation of the fort to the current condition taking into account good accessibility 
- Provide naming or marking (signage) in all areas of the fort to provide clear information on all elements of historical heritage in it

2. Tourism activities and facilities developed at the research site rely on the sociocultural potential or the value of local wisdom and the potential of the land owned, to increase the vital value and support the sustainability of the Tindoi Fort historical heritage site. The socio-cultural potential of the community is utilized by developing environmental conservation-based tourism such as protected forest exploration tours with tracking forest and Tindoi Fort roaming, developing creative economic areas that include culinary, souvenirs, and local handicrafts, developing areas that support socio-cultural values such as green open space which includes recreation, tourist attraction areas and promotion of local wisdom, providing attractive tourist areas, as well as educational forums to preserve the historical value of Tindoi Fort.

3. Drafting a design concept based on a revitalization study with a sustainable tourism approach in the context of urban design. Each aspect of the proposed design supports each other and increases the value of the fort's vitality simultaneously. In summary, the revitalization design concept is in the form of a proposed physical restoration of the fort, structuring a tourism development area based on environmental conservation, developing a creative economy center, structuring areas for supporting socio-cultural activities that support attractions and promoting local wisdom, as well as providing an educational platform to preserve the historical value of Tindoi Fort.

\section{REFERENCES}

Berry, W. (1980) Good Neighbours, Building Next to History, Historical Society of Colorado, Colorado.

Budihardjo, E. and Sidharta. (1989) Konservasi Lingkungan dan Bangunan Kuno Bersejarah di Surakarta, Indonesia, UGM Press, Yogyakarta.

Butler, R. W. (1999) Sustainable Tourism: A State of the Art Review, Tourism Geographies, 1 (1), 7-25, Routledge, United Kingdom.

Coccossis, H. (1996) Tourism and sustainability: perspectives and implications, $C A B$ International, 1-21, CAB International Europe, Europe.

Danisworo, M. (1996) Konsep Untuk Mewujudkan Keselarasan antara Pertumbuhan, Peremajaan dan Konservasi dalam Pembangunan Kota, Peremajaan dan konservasi dalam Pembangunan Kota, UNS, Surakarta.

Dinas Pariwisata dan Ekonomi Kreatif Kabupaten Wakatobi (2016) Penyusunan Rencana Induk Pembangunan Kepariwisataan Kabupaten Wakatobi, Dinas Pariwisata dan Ekonomi Kreatif Kabupaten Wakatobi, Kabupaten Wakatobi Sulawesi Tenggara.

Handoko, W. (2000) Revitalisasi Kawasan Benteng Kolonial di Wilayah Kepulauan Maluku Sebagai Bagian Pengembangan Rencana Tata Ruang Wilayah (Sebuah Gagasan Konseptual), Kapata Arkeologi, 7(13), 1-19, Kapata Arkeologi, Maluku. 
Martokusumo, W. (2008) Revitalisasi, Sebuah Pendekatan dalam Peremajaan Kawasan. Journal of Regional and City Planning, 19(3), 57-73, ITB Bandung. Mansyur, S., Somba, N., Awat, R., Ahmadi, L. A., and Hasliana. (2021) Wakatobi Islands: Archaeological, Historical, and Maritime Tradition Perspectives. Spafa Journal, 5, 1-29.

Sarfiah. (1993) Fungsi Peninggalan Sejarah Terhadap Pengembangan Pariwisata di Daerah Tingkat II Buton.

Shirvani, H. (1985) The Urban Design Process, Van Nostrand Reinhold, New York.

Suwena, I. K., and Widyatmaja, I. N. (2010) Pengetahuan Dasar Ilmu Pariwisata. Denpasar, Pustaka Larasan, Denpasar.

World Tourism Organization. (2004) Indicators of Sustainable Development for Tourism Destination, World Tourism Organization, Madrid.

Titik, Y., Dewi, T. N. and Susanti, T. (2011) Model Pengelolaan Bangunan Cagar Budaya Berbasis Partisipasi Masyarakat Sebagai Upaya Pelestarian Warisan Budaya Tahap 2, Lembaga Penelitian dan Pengabdian Universitas Katolik Soegijapranata, Semarang. 
Jauhar, Setijanti, Hayati: REVITALIZATION OF CULTURAL HERITAGE AREA WITH SUSTAINABLE TOURISM APPROACH, CASE STUDY: TINDOI FORT, KABUPATEN WAKATOBI

This Page is Intentionally Left Blank 